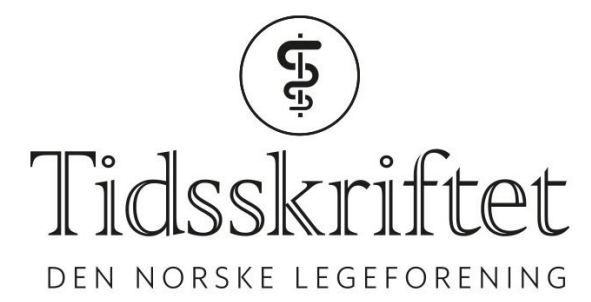

\title{
Mye mer enn tre uker i Syden!
}

KOMMENTAR

\section{TORD JOHANSEN}

E-post: tord.johansen@pefnorge.no

Tord Johansen er forbundsleder i Psoriasis- og eksemforbundet.

Forfatteren har ikke oppgitt noen interessekonflikter.

Det er dokumentert at klimabehandling fungerer som behandling for personer med psoriasis.

I artikkelen «Tre uker i Syden» på tidsskriftet.no 17. februar 2020 etterlyser Petter Gjersvik, medisinsk redaktør i Tidsskriftet og professor i hudsykdommer ved Institutt for klinisk medisin, Universitetet i Oslo, dokumentasjon på at behandlingsutbyttet for pasienter med psoriasis er godt nok til å forsvare det statlige tilbudet med behandlingsreiser til utlandet. Vi mener dette er godt utredet og vurdert i SINTEFs rapport «Evaluering av ordningen med behandlingsreiser til utlandet» fra 2011 (1). Rapporten inneholder en randomisert kontrollert studie, og flere observasjonelle studier som viser at effekten av klimaterapi er godt dokumentert (2).

PEFs interessepolitiske arbeidet mot Regjering og Storting har resultert $i$ at dette behandlingstilbudet både har fått en egen post på statsbudsjettet og ble i 2018 hjemlet i egen forskrift.

Mange med alvorlig psoriasis har stor nytte av biologisk behandling. Det blir likevel for lettvint å hevde at biologiske legemidler er et mye bedre behandlingstilbud for alle med moderat til alvorlig psoriasis. Som Gjersvik vet, kan ikke alle disse pasientene benytte biologisk behandling. For mange av disse kan klimabehandling være et helt avgjørende alternativ for å holde en krevende sykdom i sjakk.

Derfor overrasker det oss at Gjersvik setter behandlingsreiser og biologisk behandling opp mot hverandre, og hevder, på generell basis, at det ene er langt bedre enn det andre. Vi har rådført oss med vårt medisinske råd, som kan informere om at Gjersviks utspill ikke er på vegne av hele det dermatologiske fagmiljøet i landet. Vi vil på det sterkeste advare mot denne strategien, noe som i verste fall kan føre til at behandlingsreiser i utlandet for personer med psoriasis blir nedlagt. I en kamp om ressurser i helsesektoren, kan Gjersviks strategi være en gavepakke til helsepolitikere som leter etter poster på statsbudsjetter å kutte (3).

Forutsetningen for ordningen med behandlingsreiser til utlandet bør, som alle andre behandlingstilbud, vurderes ved jevne mellomrom for å tilpasses dagens situasjon. Aller helst med bakgrunn i randomiserte kontrollerte studier. Vi mener at pasienter med psoriasis har behov for både behandlingsreiser og biologisk behandling. Gjersvik er velkommen til å stille spørsmål ved behandlingseffekt og kost/nytte av klimabehandling. 
Det er helt legitimt, men da bør det baseres på oppdatert dokumentasjon, og ikke på gammel dokumentasjon og udokumenterte påstander.

\section{LITTERATUR:}

1. Evaluering av ordningen med behandlingsreiser til utlandet:

https://www.sintef.no/publikasjoner/publikasjon/?pubidCRIStin+1268252 Lest 20.3.2020.

2. Boehncke W-H. Psoriasis. Lancet. 2015:

https://www.thelancet.com/journals/lancet/article/piiSo140-6736(14)61909-7/fulltext Lest 20.3.2020.

3. Forskrift om behandlingsreiser til utlandet: https://lovdata.no/dokument/SF/forskrift/2017-o6-16-749

Lest 20.3.2020.

Publisert: 20. april 2020. Tidsskr Nor Legeforen. DOI: 10.4045/tidsskr.20.0248

(C) Tidsskrift for Den norske legeforening 2020. Lastet ned fra tidsskriftet.no 